ТЕОРІЯ ТА ІСТОРІЯ ДЕРЖАВИ І ПРАВА;

ІСТОРІЯ ПОЛІТИЧНИХ І ПРАВОВИХ УЧЕНЬ

УДК 340.132 .6

DOI https://doi.org/10.32844/2618-1258.2019.5-1.1

АНТОШКІНА В.К.

\title{
ОСНОВНІ ПІДХОДИ ДО РОЗУМІННЯ СУТНОСТІ ЮРИДИЧНОГО ТЛУМАЧЕННЯ ЯК СКЛАДНОГО БАГАТОАСПЕКТНОГО ПРОЦЕСУ
}

Вироблення зрозумілих сучасних підходів до розуміння сутності юридичного тлумачення та механізму його здійснення $є$ вкрай актуальним завданням. Мета статті - вивчення та аналіз наукового доробку вчених-правознавців як вітчизняних, так і зарубіжних щодо зазначеної проблематики, виділення основних проблемних спірних моментів у розумінні сутності юридичного тлумачення та визначення напрямів подальших наукових пошуків у цій сфері з метою вирішення теоретичних та практичних завдань.

Автор наводить найбільш типові визначення тлумачення, які викладені як упрацях фахівців із теорії права, так і інших галузей права та визначає ті характерні риси, які відрізняють тлумачення правових текстів від інших, а також найбільш спірні моменти, які містяться в традиційних і актуальних дослідженнях із вказаного питання.

У роботі вказано, що відбувається постійне оновлення теорії юридичного тлумачення, але разом із тим у нашій країні цей процес проходить доволі повільно. Фахівці із загальної теорії права намагаються інтегрувати найкращі надбання вітчизняної науки з підходами та принципами дослідників як із сім'ї континентального, так і загального права. Також можемо зазначити, що у вітчизняній правовій традиції термін «юридичне тлумачення» трактується доволі широко, адже під ним ми розуміємо тлумачення-з'ясування, тлумачення-роз'яснення, яке відбувається як у процесі створення нових нормативних актів, так і під час реалізації правових приписів із застосуванням певного визначеного інструментарію всіма суб'єктами права задля досягнення визначеного правопорядку. При цьому об'єктом тлумачення виступають як нормативні, так і індивідуальні акти. Серед вітчизняних науковців спостерігається тенденція до заглиблення у філософські аспекти інтерпретаційної діяльності, що є досить важливим, але разом із тим поза увагою залишаються питання втілення теоретичних положень і впровадження їх у практичну діяльність. Така ситуація призводить до того, що в дослідженнях фахівців з інших галузей права, як правило, використовуються підходи, що були актуальні тридцять років тому. Своєю чергою, невизначеність у наукових колах породжує ще більшу невизначеність у законотворців та осіб, які реалізують правові приписи. Законодавець не дає чітких орієнтирів, навіть не має чіткого підходу до визначення досліджуваних аспектів у текстах нормативно-правових актів. Законодавче регулювання юридичного тлумачення має фрагментарний характер, не є цілісним. Особливо вказане стосується надання роз'яснень із питань застосування законодавства компетентними державними органами, що $є$ перспективним напрямом досліджень у цій сфері.

Ключові слова: юридичне тлумачення, визначення юридичного тлумачення, оновлення теорії юридичного тлумачення, об’єкт інтерпретаиії, мета юридичного тлумачення.

(C) АНТОШКІНА В.К. - кандидат юридичних наук, доцент, доцент кафедри галузевих юридичних дисциплін (Бердянський університет менеджменту і бізнесу) 
Developing understandable modern approaches to understanding the essence of legal interpretation and its implementation mechanism is an extremely urgent task. The aim of this paper is to study and to analyze the scientific achievements of both domestic and foreign legal scholars on the mentioned subject, to highlight the main problematic issues in understanding the essence of legal interpretation and to determine the directions of further scientific researches in this sphere aimed at solving theoretical and practical tasks.

The author gives the most typical definitions of interpretation, which are presented in the papers of the theory of law and other branches of law specialists, and identifies those characteristics that distinguish legal texts interpretations from other ones, as well as the most controversial points contained in traditional and current studies on the mentioned question.

The paper indicates that there is a constant updating of the theory of legal interpretation, but at the same time in our country, such a process is proceeding rather slowly. Specialists in general theory of law are trying to integrate the best achievements of national science with the approaches and principles of researchers, both from the continental and common law families. We can also point out that in the domestic legal tradition the term "legal interpretation" is interpreted quite broadly, because by it we mean interpretation-clarification, interpretation-explanation, which occurs both while creating new normative acts and during the implementation of legal regulations with the use of certain specific tools by all subjects of law in order to achieve a certain legal order. At the same time, both the normative and the individual acts act as the object of interpretation. Among domestic scientists there is a tendency to immerse themselves in the philosophical aspects of interpretive activity, which is quite important, but at the same time, the issues of theoretical provisions embodiment and putting them into practice remain unaddressed. Such a situation leads to the fact that the researches by experts of other fields of law, as a rule, use approaches that were relevant thirty years ago. In its turn, uncertainty in academia generates even more uncertainty among lawmakers and law enforcers. The legislator does not give clear guidelines, does not even have a clear approach to the definition of the studied aspects in the texts of normative legal acts. Legislative regulation of legal interpretation is fragmentary, not holistic. The mentioned is particularly related with the provision of clarification on the application of the legislation by the competent state bodies, which is a promising area of research in this sphere.

Key words: legal interpretation, definitions of interpretation, updating of the theory of legal interpretation, object of interpretation, purpose of legal interpretation.

Вступ. Одним із важливих завдань юриспруденції є гармонізація наукового доробку вчених із текстами правових актів та правореалізаційною практикою. Вказане цілком можна зарахувати до тлумачення в праві, яке практично не має свого законодавчого закріплення. Відсутність чітких правил щодо розуміння сутності тлумачення та механізму його здійснення залишають ці питання на розсуд судій, співробітників органів виконавчої влади, правоохоронних органів. Отже, вказані особи, з одного боку, наділені значним колом повноважень щодо вирішення питань свободи, майнових прав осіб, з іншого боку - правила й основні принципи правоінтерпретаційної діяльності, яка має місце як у процесі прийняття законів, так і в процесі реалізації права, чітко не окреслена, що може негативно відбитися на характері прийнятих рішень, у тому числі призвести до зловживань. Усе це зумовлює підвищену увагу до юридичного тлумачення, вивчення його основних складників, формування чітких уявлень в юристів-практиків про правову природу і основну мету юридичного тлумачення.

Питання тлумачення в праві були об'єктом розгляду для багатьох науковців, які досліджували різні аспекти вищезазначеного явища, але в рамках цієї роботи будемо спиратися на праці А. Барака, О.М. Беляєвої, О.О. Березіної, В. Браннон, Ю.А. Вєдєнєєвої, Ю.А. Гаврилової, В.В. Гончарова, К. Грінавалта, С.З. Гурак, О.В. Капліної, М.В. Котенко, Т.В. Котяй, К. Мітчелл, В.Г. Ротаня, І.Л. Самсіна, І.А. Сердюка, Є.М. Терехова, Є.Н. Тонкова, А.Ф. Черданцева, І.Д. Шутака, А.Г. Яреми.

Постановка завдання. Метою статті є визначення основних підходів науковців, як вітчизняних, так і зарубіжних, до розуміння сутності тлумачення в праві як складного, багатоаспектного процесу в сучасних умовах розвитку суспільства, визначення та окреслення основних проблемних спірних моментів у розумінні сутності юридичного тлумачення. 
Результати дослідження. Про складність, неоднозначність та багатоаспектність тематики, яка розглядається в рамках цієї статі свідчить і той факт, що науковці у процесі вивчення та аналізу питань теорії юридичного тлумачення застосовують цілу групу термінів: тлумачення права; тлумачення в праві, тлумачення закону; тлумачення нормативно-правового акта; юридичне тлумачення; тлумачення норм права; правоінтерпретаційна діяльність, тлумачення договорів, практика тлумачення, інтерпретація права, теорії тлумачення, правозастосовне тлумачення. Вважаємо в рамках статті за доцільне використовувати термін «юридичне тлумачення» як більш «широкий» за змістом. Отже, спробуємо окреслити, що ми розуміють під вказаним терміном і які основні проблеми так і не знайшли остаточного вирішення у вказаній сфері.

С.3. Гурак у статті аналізує питання, яке завжди висвітлюється у процесі розгляду юридичного тлумачення: чи підлягає йому будь-який закон? Вона зауважує, що на перший погляд тексти законів є доступними для сприйняття та розуміння. Разом із тим норми права мають абстрактний характер, і основне завдання - співвіднести їх із конкретними життєвими ситуаціями, які відрізняються одна від одної в тому чи іншому аспекті. Часто з цим можуть впоратися тільки професійні юристи, в яких є досвід минулого індивідуального тлумачення, а також досвід тлумачення інших суб'єктів. Отже, вищезазначене та особливості формулювання норм права (лаконічність, спеціальна термінологія, тощо), їх змістовні зв'язки з іншими нормами, відсилання до інших норм та недоліки законодавчої техніки, на думку автора, породжують необхідність тлумачення всіх нормативно-правових актів [1, с. 29].

На підтвердження вказаної тези О.М. Бєляєва ставить у роботі питання: чи є такий чіткий, беззаперечний критерій, за яким всі нормативно-правові акти можна поділити на зрозумілі та незрозумілі та визначити окремо способи тлумачення для кожної з таких груп? Як вона цілком слушно зазначає, вказане цілком неможливо реалізувати на практиці [2, с. 45].

Вважаємо за необхідне наголосити на дуже важливому моменті - подвійній природі тлумачення, а саме: воно не мало б особливого значення, якби зводилось тільки до розуміння змісту тексту тими, хто його читає. Тлумачення права відрізняється від тлумачення інших письмових документів дійовим характером, оскільки метою такого розуміння $є$ реалізація приписів в поведінці суб'єктів права [3, с. 21].

Отже, інтерпретації права не зводяться до реконструкції формальних та політичних передумов і умов прийняття, реалізації та застосування правил поведінки в соціальній практиці. Формальне тлумачення - категорія низької критики процесу правозастосування, яка визначається колізією норм права. Топіка інтерпретації формується культурно-історичним контекстом і системою ціннісних підстав соціального спілкування, а її предмет визначається колізією правових цінностей і формальних норм. Правова екзегетика і правова герменевтика є двома полюсами теоpiї і практики інтерпретації права в його догматичному і соціокультурному вимірі - формального тексту і культурно-історичного контексту [4, с. 33, 39].

Наведемо кілька цілком типових визначень тлумачення, які містяться у вітчизняній правовій літературі. Наприклад, М.В. Котенко під тлумаченням норм права розуміє інтелектуально-вольову діяльність (внутрішній процес мислення, який здійснюється особою з допомогою способів тлумачення), спрямовану на з'ясування і роз'яснення волі законодавця, матеріалізованої в нормі права, а також результати цієї діяльності. При чому тлумачення має місце при всіх формах юридичної діяльності: від правотворення до наукової діяльності. Предметом тлумачення норм права є: норма права, її текст, пов'язані з нею правові та не правові джерела та об'єкт - воля законодавця [5, с. 262].

T.В. Котяй визначає тлумачення норм права як різновид юридичної діяльності, що має пізнавальний характер, грунтується на певних принципах і здійснюється відповідним суб'єктом із метою відшукання й уточнення змісту норм права, а в певних випадках передбачає також його роз'яснення для інших суб'єктів. Тлумачення норм права - це, з одного боку, певний розумовий процес, спрямований на встановлення змісту норм права за допомогою його способів (зміст тлумачення), а з іншого - результат зазначеного розумового процесу, що знаходить вираження в сукупності суджень, в яких розкривається зміст норм, що тлумачаться. Результат тлумачення об'єктивується в усній або письмовій формі [6, с. 16].

Ще $є$ приклад визначення галузевих фахівців, а саме: правозастосовне тлумачення норм кримінально-процесуального права - це інтелектуально-вольова діяльність суб'єктів тлумачення, спрямована на з'ясування смислу (суті, змісту) норми права з метою правильного ії застосування, а також роз'яснення засвоєного, що об'єктивується в акті тлумачення [7, с. 22].

Отже, що цілком зрозуміло, більшість дослідників у визначеннях тлумачення в праві зосереджуються саме на тлумаченні правових норм. При цьому зазначається, що договори норматив- 
ного характеру (наприклад, міжнародні, колективні та ін.), що містять норми права, розглядаються як джерела права та їх тлумачення мало чим відрізняється від тлумачення інших нормативних актів. Також А.Ф. Черданцев у роботі «Тлумачення права та договору» слушно зауважує, що в тлумаченні норм права (нормативних актів і правочинів, інших індивідуальних актів) більше спільного, ніж відмінностей [8, с. 316-317], тому можемо використовувати у процесі тлумачення останніх всі напрацювання загальної теорії права в цій сфері з урахуванням їхньої специфіки.

На підтвердження цього наведемо визначення О.О. Березіної, яка під тлумаченням індивідуально-правових договорів розуміє особливий різновид юридичного тлумачення, що являє собою здійснювану за допомогою традиційних способів юридичного тлумачення та способів, що випливають з особливостей індивідуально-правових договорів, специфічну юридичну діяльність сторін договору, їх представників, судових органів й інших суб'єктів права, спрямовану на пізнання змісту умов індивідуально-правових договорів із метою їх безпосередньої або опосередкованої реалізації [9].

Отже, як бачимо 3 наведеного вище, загальновизнаним є виокремлення в юридичному тлумаченні кількох стадій: тлумачення-з'ясування та тлумачення-роз'яснення, а також наявності певного інструментарію (способи тлумачення) та мети - реалізація приписів.

Вважаємо за потрібне зупинитися на наступному аспекті тлумачення в праві, на який звертають увагу М.Н. Брагінський та В.В. Вітрянський: у різні історичні часи правоінтерпретаційна діяльність була спрямована або на встановлення змісту закону, або на пошук волі законодавця і навпаки [10, с. 215], що можемо прослідкувати також у наведених вище визначеннях.

Наприклад, О.Д. Овчинникова, А.М. Шаганян говорять, що складність процесу тлумачення зумовлена, зокрема, тим, що фактично інтерпретатор, аналізуючи зміст правової норми, має за допомогою розумової діяльності відтворити справжню волю законодавця, яка була закладена в самій процедурі правотворчості [11, с. 23].

Натомість інші вчені не погоджуються, що виявлення волі законодавця в тексті нормативно-правового акта є метою правоінтерпретаційної діяльності. Адже на практиці прийняття законів - складний, упорядкований процес, колективна процедура, в якій задіяна велика кількість людей, наділених відповідними повноваженнями в цій сфері. Крім того, кожна із цих осіб під час формування текстів нормативно-правових актів, обговорення та внесення поправок може вкладати в його текст власний сенс.

Таким чином, дедалі очевиднішим стає той факт, що основоположною метою сучасної правоінтерпретаційної діяльності виступає розкриття змісту норм права. На цей процес впливають економічні, політичні, соціальні, культурні зміни, що відбуваються в суспільстві, які враховуються суб'єктами правоінтерпретаційної діяльності у процесі видання актів тлумачення права. Саме тому варто зауважити, що необхідність встановлення волі законодавця еволюційно застаріла і не є актуальною для сучасної правоінтерпретаційної діяльності [12, с. 55].

Також наведемо такий аргумент. Право, як і інші соціальні феномени, виробляє і відтворює особливу соціальну волю («волю правову»). Особливість правової волі зумовлена ії цілями i засобами їх досягнення. Цілями правової волі визначається, які елементи і в якій послідовності продукуються сутністю в змісті права. Отже, право знаходить якісну визначеність, утворює «завершене» соціальне явище, коли його сутність, сформувавши зміст права, досягає своїх кінцевих цілей. Але кінцевою метою не є створення правових норм, оскільки правова воля реалізує себе, задовольняє соціальні правові потреби, що ії зумовили, лише в правомірній поведінці суб'єктів соціального життя, в досягненні правопорядку. Можна зробити висновок, що правові приписи, як і інші правові явища, виступають лише як проміжні ланки в процесі досягнення сутністю кінцевого результату [13, с. 229].

Ще одне питання, що потребує визначення: використання термінів «інтерпретація» та «тлумачення» в наукових роботах, правозастосовних актах, законодавстві.

Одна з точок зору на співвідношення тлумачення та інтерпретації полягає в тому, що вони не мають ототожнюватися, хоча і розглядаються як споріднені категорії. Причому право інтерпретаційна діяльність є своєрідним еталоном для вироблення правових позицій, а тлумачення норм має підконтрольний характер [14, с. 91].

Якщо звернемося до практики інших держав, то інтерпретація (interpretation) в англійському праві не збігається з тлумаченням (constraction) у «суворому» значенні терміна, оскільки цей процес розділено на дві стадії, а саме: 1) власне розумовий процес усвідомлення змісту нормативного акта, 2) діяльність, яка виражається назовні, пов'язана з роз'ясненням своєї точки зору щодо сенсу правової норми іншим [15, с. 38$]$. 
Ю.А. Гаврилова пропонує застосовувати в наукових дослідженнях термін «інтерпретація» в значенні доктринального тлумачення, а в законодавстві і практичній діяльності - як тотожний «тлумаченню», а не як альтернативу останнього. Вона висловлює побоювання, що в іншому випадку, з урахуванням певних негативних особливостей правової дійсності, це може призводити до зловживань, коли кожен суб'єкт під виглядом інтерпретації буде підміняти об'єктивний зміст законодавчих приписів своїм суб'єктивним змістом, який на його думку і буде «істинним» [16, с. 87-88]. Вважаємо, що останній підхід є досить раціональним і відповідає традиціям, які склалися щодо досліджуваних явищ у нашій країні.

У цій частині статті вважаємо за необхідне розглянути, як і в яких напрямах розвиваються думки дослідників щодо визначення місця, сутності, завдань тлумачення в праві, з урахуванням підходів вітчизняних і зарубіжних авторів.

Нове методологічне значення юридичної інтерпретації полягає в тому, що вона розглядається як явище, інтегроване в структуру будь-якої юридичної діяльності, невід’ємний компонент юридичного дискурсу. Традиційний діяльнісний підхід виходить із позицій, що тлумачення - самостійний різновид юридичної діяльності, спрямований на пізнання і роз'яснення змісту правових текстів. Однак автор зауважує, що протиставляти, розділяти вказані аспекти у сфері юридичної інтерпретації недоречно, оскільки в повсякденному житті вони знаходяться в тісному взаємозв’язку один з одним. На думку Ю.А. Гаврилової, можна виділити дві сучасні концепції юридичної інтерпретації: мовну (об'єктом є сенс правового тексту, тобто інформаційний зміст, який визначається діапазоном значень, словами і пропозиціями, що включається до нього, його внутрішньосистемним контекстом, а також місцем і роллю в правовій системі суспільства) і дискурсивну (об'єктом виступає те, який сенс права загалом, або сенс того явища правової дійсності, яке інтерпретується як таке, що має нетекстуальну форму: правосвідомість, правова поведінка, суб'єктивні права і юридичні обов'язки і т.п.) [17, с. 201-202].

I.A. Сердюк зауважує, що тлумачення норм права є «складним багатогранним явищем правової дійсності» і пропонує визначення з урахуванням різних його аспектів: 1) гносеологічного - як пізнавальний процес з'ясування та роз'яснення волі законодавця; 2) методології права як сукупність методів, які використовує суб'єкт права для встановлення смислу та змісту норм права; 3) в аспекті теорії правовідносин - як реальні дії уповноваженої сторони управлінських правовідносин із реалізації належних їм державно-владних повноважень щодо офіційного тлумачення норм об'єктивного права; 4) з погляду теорії юридичних фактів - як юридичний акт, що слугує фактичною підставою для виникнення, зміни чи припинення правовідносин; 5) в аспекті взаємозв'язку із процесом правового регулювання - як його стадію; 6) взаємозв'язку із функціями держави як форму здійснення функцій держави [18, с. 41].

Тут доцільно також згадати монографію «Тлумачення закону і права», в яку входять роботи авторів, присвячені різним аспектам тлумачення: від вивчення герменевтичних просторів знакових систем до статей про правовий реалізм, що об'єднує американські, скандинавські і російські варіанти цього феномена в єдиний понятійний ряд, за редакцією Є.М. Тонкова. Останній також наводить своє бачення юридичного тлумачення, яке він дає через розгорнуте визначення стадій тлумачення, вказуючи, що тлумачення-з'ясування, тлумачення-роз'яснення, тлумачення-застосування $з$ точки зору цілей, функцій і компетенцій інтерпретатора істотно розрізняються. Заслуговують на увагу думки автора щодо впливу особистості інтерпретатора, його індивідуальної правосвідомості, рівня кваліфікації на інтерпретаційні можливості. При цьому початковий етап процесу - визнання норми, що інтерпретується, як обгрунтованого, необхідного законодавчого припису. Суб’єкт тлумачення, систематизувавши правову дійсність, цілеспрямовано впливає на іiі окремі сторони за допомогою роз'яснення правил належної поведінки і застосування інтерпретованих ним норм до конкретних юридичних фактів і правовідносин. Для реалізації своїх завдань у контексті індивідуальної ієрархії цінностей інтерпретатор гармонізує результати свого тлумачення з думкою референтної спільноти. На прикладі правової системи своєї країни вчений говорить про те, що наявній у ній стандарти не визначають основною метою врегулювання спору, відновлення прав, встановлення справедливості, а тому інтерпретатори (судді, прокурори, державні службовці та ін.) приймають рішення, які легше обгрунтувати як у текстуальному, так $i$ в понятійному сенсі, які лежать на поверхні, не суперечать думці колег правознавців, а особливо «керівній лінії» виконавчої та законодавчої влади [19].

Як цілком слушно зазначає В.В. Гончаров, вчені-правознавці радянського періоду тяжіли до суб'єктивної теорії тлумачення, оскільки тогочасному тоталітарному режиму повністю відповідала теза про необхідність встановлення під час тлумачення «закладеної в законі волі законо- 
давця», а суд при цьому був «ніби агентом законодавця, підпорядкованою інстанцією, що втілює волю останнього в життя». У сучасних умовах вимогам до теорії тлумачення найбільше відповідає синтетична теорія, яка «потенційно здатна досягти найповнішої цілісності інтерпретації права та іiі справедливості». Він зазначає іiі основні характеристики, які, на його думку, мають свідчити на їі користь: узгодженість із новою герменевтичною методологією; поєднання «різнорідних правотлумачних аргументів»; вирішення ситуації на підставі оцінки ваги правотлумачних аргументів, якщо їх неможливо поєднати; дотримання принципу усталеної практики тлумачення, за можливості виключень; «урахування балансу цінностей, які стоять на кону судового рішення». При цьому В.В. Гончаровим висловлені сподівання про невідворотність процесу «зміни парадигми юридичної інтерпретації», відходу від старої методології [20, с. 55, 66].

Е.Ю. Вікторова у статті розглядає, як відбувається процес виявлення змісту правової норми в Англії і США. Авторка зазначає, що найбільш затребуваним є так званий текстуальний підхід, у рамках якого об'єктом тлумачення виступає текст закону, однак теорії тлумачення, що базуються на виявленні намірів законодавця, активно розробляються і використовуються як альтернатива. Наприклад, в американській доктрині та судовій практиці прийнято розрізняти: 1) конкретний намір законодавця, коли визначаються межі дії закону в часі, в просторі і по колу осіб; 2) абстрактний намір законодавця, для виявлення якого особа, яка застосовує норми, ніби «встає на місце» законодавця і вирішує питання, прямо не врегульоване законом; 3) спільний намір законодавця, що виражається у встановленні спільної мети прийняття закону, того завдання, за допомогою якого його можна вирішити.

В обох вказаних підходах є переваги та недоліки, ось чому тривають дискусії в судових засіданнях і доктринальних роботах про допустимість і доцільність виявлення в процесі тлумачення закону намірів законодавця і співвідношенні цільового підходу із текстуальним, в яких навряд буде поставлена крапка [21, с. 187].

А. Барак у роботі 2005 року «Мета тлумачення в праві» у розділі 1 «Що таке правове тлумачення» пише, що розрізняє тлумачення у вузькому розумінні - тлумачення, яке надає значення юридичному тексту, та тлумачення в широкому розумінні, яке включає заповнення прогалин у неповному тексті. Пояснення другого підходу до тлумачення грунтується на тому, що він, зрештою, надає значення тексту, визначає нормативне повідомлення, що випливає 3 нього. Пояснюючи, чому він наполягає на розрізненні тлумачення в широкому і вузькому розумінні, А. Барак зазначає, що стандарти, які регулюють ці два види діяльності, різні, оскільки дві окремі і чіткі системи регулюють тлумачення наявного тексту та заповнення прогалин неповного тексту. При цьому зазначається, що вирішення питань і підходів до розуміння тлумачення залежить від відповідної правової традиції [22, с. 5-6].

В. Бод і C.Е. Сакс у роботі «Закон інтерпретації» розглядають, зокрема питання щодо визначення об'єкта тлумачення, а саме: чи вважати доповіді комітетів або відповідні висловлювання керівників матеріалом, який варто тлумачити - чи вважаються вони «актами законодавців» (йдеться про процедури прийняття законів Конгресом). Автори пропонують застосовувати аналогію з приватним правом, де діє правило про те, що письмова угода скасовує попередні домовленості сторін, а отже, вважають, що все, що має значення для тлумачення, включено в сам закон. Вони наголошують, що це не просто правило тлумачення, це правило, що визначає предмет тлумачення, тобто конкретні аспекти взаємодії сторін, які насправді мають юридичну силу [23, с. 1112-1114].

В.К. Браннон у роботі «Статутна інтерпретація (Тлумачення закону): теорії, інструменти та тенденції» висвітлює різні підходи до тлумачення. Розглядаючи цільовий підхід до тлумачення закону, вона зазначає, що при його застосуванні суди мають тлумачити неоднозначний текст «таким чином, що відповідає цілям Конгресу». Представники цього підходу пропонують виходити 3 того, що «законодавча влада складається з розумних людей, які розумно переслідують розумні цілі». Інтерпретатору треба спиратися на політичний контекст закону, шукаючи «докази, які спонукали розумну людину, яка розбирається з обставинами, що лежать в основі закону, і сприятимуть виправленню помилки».

Представники текстуального підходу зосереджуються на формулюваннях закону, надаючи перевагу тексту акта над його незакріпленою метою. Вони стверджують, що суди мають розуміти положення правового акта так, як їх розуміє будь-який член Конгресу. Отже, необхідно шукають сенс, який розумна людина виводить із тексту закону [24].

У монографії К. Мітчелл «Тлумачення договорів» також розглядається питання визначення юридичного тлумачення. Нею висловлена думка, з якою важко не погодитися, що це питання 
складне, оскільки «тлумачення» за своєю природою є незрозумілим поняттям. Вона зауважує, що важко запропонувати певний широко прийнятий підхід щодо того, що таке тлумачення, оскільки майже все, що стосується тлумачення, викликає спори. Наприклад, прихильники текстуального (або буквального) тлумачення вбачають завдання тлумачення в поясненні тексту, який $є$ переважно самодостатнім і може тлумачитись без посилання на сторонні джерела. Натомість прихильники контекстуального підходу до тлумачення вказують, що, окрім тексту для тлумачення, важливо також враховувати інші матеріали. Своєю чергою, прихильники цільового підходу до тлумачення вважають, що варто враховувати намір автора тексту. Якщо підсумувати такі дискуciï, то зазвичай протиставляються два підходи: буквального та контекстуального або буквального й цільового тлумачення [25, с. 4-5].

К. Грінавалт у роботі «Основи правової інтерпретації: основні елементи та критичні варіації» зазначає, що подібно до інших правових категорій термін «тлумачення» не має чіткого визначення. Він пише, що питання щодо різного використання цього терміна виникає тоді, коли вирішуються межі повноважень суддів, проте основне питання стосується правових зобов'язань окремих осіб, посадовців та суддів, що не має залежати від того, використовується термін «тлумачення» у вузькому чи широкому сенсі [26].

У рамках цього дослідження хотілося б особливо зазначити навчальний посібник «Новітнє вчення про тлумачення правових актів», який є особливим явищем вітчизняної науки, оскільки, як зазначають його автори, наукові пошуки стосовно проблем тлумачення в праві є досить абстрактними, тяжіють до філософії, разом із тим є нагальна потреба виробити чіткі рекомендації, наскільки це можливо, щодо застосування всього інструментарію тлумачення, визнаного сучасною правовою наукою для вирішення практичних задач. Автори, використовуючи приклади 3 чинного законодавства, грунтовно і послідовно показують, як використовувати ті чи інші способи і правила тлумачення особам, які застосовують правові приписи. Саме наукові пошуки на межі теорії права та інших галузей права є не просто актуальними, а й необхідними [27].

Висновки. Підсумовуючи викладене, можемо сказати, що стосовно нашої правової системи відбувається постійне оновлення теорії юридичного тлумачення, але разом із тим цей процес проходить доволі повільно. Як правило, питання юридичного тлумачення розглядаються в роботах фахівців із загальної теорії права, які намагаються інтегрувати найкращі надбання вітчизняної науки 3 підходами та принципами дослідників як із сім’ї континентального, так i загального права. Можемо також зазначити, що у вітчизняній правовій традиції термін «юридичне тлумачення» трактується доволі широко, під ним ми розуміємо тлумачення-з'ясування, тлумачення-роз'яснення, яке відбувається як під час створення нових нормативних актів, так і під час реалізації приписів із застосуванням певного визначеного інструментарію всіма суб'єктами права задля досягнення визначеного правопорядку. При цьому як об'єкт тлумачення виступають як нормативні, так і індивідуальні акти. Також зазначимо, що спостерігається тенденція до заглиблення у філософські аспекти, без врахування потреб практики, що не $\epsilon$ виправданим, адже нагальна потреба - об'єднати вказаний підхід із практичним аспектом. Вказана ситуація призводить до того, що в дослідженнях галузевих фахівців, як правило, використовують підходи, що були актуальні тридцять років тому. До того ж така ситуація невизначеності в наукових колах породжує ще більшу невизначеність у законотворців та осіб, які реалізують правові приписи. Законодавець не дає чітких орієнтирів, навіть не має чіткого підходу до визначення досліджуваних аспектів у текстах нормативно-правових актів. Законодавче регулювання тлумачення має фрагментарний характер, не є цілісним. Особливо вказане стосується надання роз'яснень із питань застосування законодавства компетентними державними органами, що є перспективним напрямом досліджень у цій сфері.

\section{Список використаних джерел:}

1. Гурак С.3. Необхідність тлумачення для цілей реалізації правових приписів. Науковий вісник Ужгородського національного університету. 2013. Серія ПРАВО. Випуск 21. Частина II. Том 1. С. 27-29.

2. Беляева О.М. Толкование норм права. Ученые записки Казанского государственного университета. Том 149, кн. 6. Гуманитарные науки, 2007. С. 39-47.

3. Шутак І.Д. Юридична техніка тлумачення норм права. Науково-інформаційний вісник. Право. 2015. № 11. С. 18-24.

4. Веденеев Ю.А. Интерпретации права как культурно-исторический феномен: категория и институт. Актуальные проблемы российского права. 2016 . № 5 (66). С. 32-46. 
5. Котенко М.В. Тлумачення норм права в системі юридичної діяльності. Ученые записки Таврического наџионального университета им. В.И. Вернадского. Серия «Юридические науки». 2012. Том 25 (64). № 1. С. 258-263.

6. Котяй Т.В. Тлумачення закону про кримінальну відповідальність: поняття, види, значення : автореф. дис. ... канд. юрид. наук : 12.00 .08 «Кримінальне право та кримінологія; кримінально-виконавче право». Нац. юрид. ун-т ім. Ярослава Мудрого. Харків : Б.В., 2019. 20 с.

7. Капліна О.В. Правозастосовне тлумачення норм кримінально-процесуального права : моногр. Харків : Право, 2008. 296 с.

8. Черданцев А.Ф. Толкование права и договора. Москва, 2003. 381 с.

9. Березина Е.А. Толкование договора как вид юридического толкования : автореф. дис. ... канд. юрид наук : 12.00.01 / Уральская государственная юридическая академия. Екатеринбург, 2001. 26 c. URL: https://www.dissercat.com/content/tolkovanie-dogovora-kak-vid-yuridicheskogotolkovaniya (дата звернення 10.11.2019).

10. Брагинский М.Н. Договорное право / М.Н. Брагинский, В.В. Витрянский. Москва : Статут, 1997. 682 с.

11. Овчинникова О.Д., Шаганян А.М. Некоторые проблемы интерпретации норм права. Юристъ-Правоведъ. 2017. № 4 (83). С. 22-26.

12. Терехов М.Е. Анализ целевой составляющей правоинтерпретационной деятельности. Правовая парадигма. 2017. Т. 16. № 3. С. 52-56.

13. Петров А.В. Форма права и ее разновидности. Вестник Нижегородского университета им. Н.И. Лобачевского. 2012. № 6 (1). С. 227-232.

14. Терехов Е.М. Сравнительно-правовой анализ понятий «право интерпретационная деятельность» и «толкование права». Правовая парадигма. 2019. Т. 18. № 1. С. 88-92.

15. Тонков Е.Н. Английская техника толкования закона. Вестник Нижегородской академии МВД России. 2013. № 24. С. 37-40.

16. Гаврилова Ю.А. Толковать Нельзя интерпретировать. Правовая парадигма. 2018. Т. 17. № 3. С. $83-90$.

17. Гаврилова Ю.А. Юридическая интерпретация в российском праве: единство методологического и деятельностного подходов. Вестник РУДН. Серия: Юридические науки. 2019. Т. 23. № 2. 200-218.

18. Сердюк I.А. Методологічний аналіз інтерпретацій поняття «тлумачення норм права». Науковий вісник Дніпропетровського державного університету внутрішніх справ. 2014. № 3. C. 35-43.

19. Толкование закона и права. Т. 1. Под общей редакцией Е.Н. Тонкова. «Алетейя». 2015. 205 c. URL: https://mybook.ru/author/kollektiv-avtorov/tolkovanie-zakona-i-prava-tom-i/read/?page=1 (дата звернення 15.11.2019).

20. Гончаров В.В. Від старої теорії тлумачення до нової: основні виклики та рішення. Філософія права $і$ загальна теорія права. 2014. № 1-2. С. 53-69.

21. Викторова Э.Ю. Теория выявления намерения законодателя в толковании права в Англии и США. Труды Института государства и права РАН / Pro cee dings of the Institute of State and Law of the RAS. 2019. T. 14. № 2. C. 186-206. DOI: 10.35427/2073-4522-2019-14-2-viktorova.

22. Aharon Barak «Purposive Interpretation in Law». Translated from the Hebrew by Sari Bashi. 2005. Published by: Princeton University Press. URL: http://assets.press.princeton.edu/chapters/s7991. pdf (дата звернення 23.10.2019).

23. William Baude, Stephen E. Sachs. The law of interpretation. Harvard Law Review. 2017. Vol. 130. No. 4 URL: https://books.google.com.ua/books?id=8jcNDgAAQBAJ\&pg=PT46\& $\mathrm{lpg}=\mathrm{PT} 46 \& \mathrm{dq}=$ everyone + relies + on + the + committee+summaries+instead $.193 \&$ source $=$ bl\&ots $=$ uqkLI0ftc \&sig=ACfU3U2qajSs54VSdAD-GtQd4NKEvEWyeQ\&hl=ru\&sa=X\&ved=2ahUKE wit38Gvo9bmAhWawsQBHZ2HA2EQ6AEwCnoECAsQAQ\#v=onepage\&q=everyone $\% 20$ relies $\%$ 20 on $\% 20$ the $\% 20$ committee\%20summaries\%20instead.193\&f=false (дата звернення 23.10.2019).

24. Valerie C. Brannon "Statutory Interpretation: Theories, Tools, and Trends". URL: https://fas.org/sgp/crs/misc/R45153.pdf (дата звернення 25.10.2019).

25. Catherine Mitchell "Interpretation of Contracts". Routledge, 2007. 176 p.

26. Kent Greenawalt "Realms of Legal Interpretation: Core Elements and Critical Variations". Oxford University Press, 2018. 168 p. URL: https://books.google.com.ua/books?id=0gJfDwAAQBA$\mathrm{J} \&$ printsec $=$ frontcover $\& \mathrm{dq}=$ Realms + of + Legal + Interpretation $\& \mathrm{hl}=$ ru\&sa $=$ X\&ved $=0$ ahUKEwjl6bfp3YflAhU6wcQBHfo4DNMQ6AEIKDAA\#v=onepage \&q=Realms\%20of\%20Legal\%20Interpretation\&f=false (дата звернення 04.11.2019). 